\title{
Life cycle management in bakeries: a proposed roadmap towards sustainability
}

\author{
Nathalie Barbosa Reis Monteiro' ${ }^{1}$. José Machado Moita Neto ${ }^{2}$. Elaine Aparecida da Silva ${ }^{3}$
}

Received: 21 July 2021 / Accepted: 19 November 2021 / Published online: 27 November 2021

(c) The Author(s), under exclusive licence to Springer-Verlag GmbH Germany, part of Springer Nature 2021

\begin{abstract}
Purpose Some commercial/industrial sectors have increased their interest in sustainability, in some cases changing their business focus, from a profit-centered approach to a more balanced view, including environmental and social factors. It means that the interest in sustainability is increasing. Life cycle management (LCM) is a methodology/concept that can contribute to this paradigm shift. In this research, the potential application of LCM in the bakery segment was investigated, considering the entire value chain related to the sector (inputs, packaging, suppliers, customers, waste management).

Methods Bakeries were visited, in Teresina, Piauí, Brazil, to learn about the products, services, production processes, and the socio-environmental and economic sustainability practices, aiming at identifying bottlenecks and to propose alternatives based on LCM. Besides the field approach, the study was structured based on the literature that brings the concepts and potentialities of applying LCM in various economic/industrial sectors. The PDCA cycle and the SWOT Matrix were also used to assist the implementation of LCM. A roadmap was proposed aiming at the LCM implementation in bakeries. Results The results show that although the sector has some environmentally sustainable practices (waste separation, energy savings, reuse of products, inputs purchased locally), the primary intention is to reduce costs and not to mitigate environmental impacts. Regarding social responsibility, they donate bread to institutions. This is an important attitude, but not the only one for fulfilling the social role within the value chain. They do not consider suppliers that show concern for the environment (certified companies), and both marketing and product labels do not evoke these issues too.

Conclusions and recommendations Thus, there is the possibility of implementing LCM in bakeries if there is a concern with sustainable production and consumption. A roadmap for implementing LCM in bakeries was proposed including some steps: mapping the life cycle of products/processes/services associated with the sector; analyzing factors that can influence the actions towards sustainability; disseminating life cycle information to the entire value chain; efficient waste management, including the partnership with recycling companies; and treatment of the collected data and improvement proposal, using management tools such as the PDCA Cycle, the SWOT Matrix, and Environmental, Social and Governance (ESG) aiming at the search for environmental and economic sustainability and social fair alternatives.
\end{abstract}

Keywords Environmental sustainability $\cdot$ Life cycle $\cdot$ LCM $\cdot$ Bakery

Communicated by Niels Jungbluth.

Nathalie Barbosa Reis Monteiro

1 Centro de Ciências Sociais e Aplicadas, Universidade Presbiteriana Mackenzie, Rua da Consolação, São Paulo, SP 01302907, Brazil

2 Doutorado em Desenvolvimento e Meio Ambiente, Universidade Federal do Piauí, Avenida Universitária, Teresina, PI 64049550, Brazil

3 Centro de Tecnologia, Departamento de Recursos Hídricos, Geotecnia e Saneamento Ambiental, Doutorado em Desenvolvimento e Meio Ambiente, Universidade Federal do Piauí, Avenida Universitária, Teresina, PI 64049550, Brazil

\section{Introduction}

The paradigm changes in the business world from a vision focused essentially on profit to a more balanced approach, which includes environmental, governance, and social factors, tend to become a differential for companies to remain competitive in the global and domestic market. Life cycle management (LCM) proposes the assessment of the life cycle of products, processes, and services, including the enterprise's entire chain (upstream and downstream). This links the management of sustainability and the performance of organizations and products with the creation of value. 
This concept absorbs cost savings, risk management, and compliance, integrating them so that sustainability becomes a differentiation element in the market (Rebitzer 2015).

Thus, LCM is a concept and a practice of companies that incorporate sustainability as part of their business routine, making the management of environmental and social issues, in an economic context, no longer a business cost, becoming a driver of the company's activities in the market (Manda et al. 2015). The concern with sustainability generates a series of attitudes in the business environment that promote environmental and social benefits once the industries start looking for alternatives so that their production processes cause the least possible aggression on the environment. Even products whose life cycle management is economically unsustainable today, in the future, they may gain market share when people's perceptions change about environmental issues.

Profitability is measured not only when there is an increase in sales, but also when adopting productive processes that promote savings in terms of reducing water/ energy/waste, and proactive activities related to environmental and social issues (Xie et al. 2019). This can be summarized in Profit $=$ Revenue - Cost of Production (Finance Strategists 2021). By adopting sustainable practices, such as water reduction and energy saving, it may improve the profitability at the same time that improves sustainability once such actions save money and natural resources. In some cases, the economic benefits of sustainability are perceived in short-term actions, such as when the initiatives significantly reduce the consumption of energy and resources, which internally provide financial benefits to the company. However, in other cases, sustainability actions come with costs and do not provide short-term financial incentives (Gemechu et al. 2015). Companies need to realize the positive long-term consequences, which can improve their attractiveness to the consumer and increase their competitiveness in the market.

With this in mind, according to Simon (2015), marketing has its role in convincing society about the concern with sustainability, and Kishita et al. (2018) affirm that environmental education is the best way to change society's mentality and perception of environmental issues. The goal is that thinking about the life cycle of products becomes part of the companies' routine to reduce their environmental and socioeconomic burden, seeking to maximize their economic and social value. The concept can be applied to all types of companies (Sonnemann et al. 2015; Life Cycle Initiative 2021).

LCM helps in the incorporation of sustainability systemically. Regarding the company's value chain, for example, its dynamics extend in several directions, connecting end users to suppliers and manufacturers. There are management institutions and business associations that provide LCM structures for corporations, for example, the Instituto Brasileiro de Informação em Ciência e Tecnologia (IBICT) ${ }^{1}$ (in English Brazilian Institute of Information in Science and Technology) and the Life Cycle Initiative, ${ }^{2}$ accompanied by training and research on the most appropriate metrics for each context. Companies like EMBRAPA-Empresa Brasileira de Pesquisa Agropecuária ${ }^{3}$ (in English Brazilian Agricultural Research Company) have LCM initiatives within the company and support events such as the Congresso Brasileiro Sobre Gestão do Ciclo de Vida (Brazilian Congress on Life Cycle Management), encouraging and helping to disseminate life cycle thinking to society.

However, there is not a universal structure for LCM once there are different approaches for the methodology (Balkau et al. 2015), which leads to the need for different choices for its application. Thus, it is necessary to involve stakeholders and demonstrate that changes have a positive impact, as well as highlighting actions that need to be reviewed and adjusted to adapt to a more sustainable production model (SeidelSterzik et al. 2018). According to Sonnemann et al. (2015), the results achieved by LCM, normally, are more applicable in the improvement of products and marketing, through the reduction of waste, improvements in technologies, creation of new markets, and reduction of liabilities. This must be increased with the use of more robust and universal methodologies that promote the optimization of systems.

Industries, from the most diverse sectors, must find ways to develop tools that adapt to their reality and their products and production processes. Thus, the idea of a company can, and should, be replicated in other enterprises so that sustainability becomes a differential that results in economic, social, and environmental benefits, contributing to the formation of a more equitable and just society. In this paper, the analysis in the bakeries was made on the life cycle management necessary for the activity to become more sustainable from the environmental, economic, and social points of view.

There are very few studies that address the bakery sector and LCM, which became one of the motivations for the research. Performing a search on the Coordination of Improvement of Higher Education Personnel (CAPES) Portal (CAPES 2021), with the combination of the keywords "bakery," "bakeries," "life cycle assessment," "life cycle management," "LCA," and "LCM," in the last 10 years, only seven studies were found (Styles et al. 2016; Chiriaco et al. 2017; Bacenetti et al. 2018; Noya et al. 2018; Svanes et al. 2018; Yadav and Garg 2019; Cappelli and Cini 2021). Thus, this study aimed to propose ways to apply LCM in

\footnotetext{
1 Available in: https://www.ibict.br/

2 Available in: https://www.lifecycleinitiative.org/starting-life-cyclethinking/life-cycle-approaches/life-cycle-management/

${ }^{3}$ Available in: https://www.embrapa.br/vcbgcv/gcv
} 
bakeries to improve sustainability in this sector and to increase scientific production with this approach. The novelty of this study is to show several ways to implement LCM in this sector since none of the studies found in the literature brings this complete approach in a single paper. The findings of this research can be applied in other sectors that commercialize similar products (restaurants, snack bars, etc.) or can be adapted to other commercial/industrial sectors as well.

The studies that address LCM/LCA in bakeries are from different points of view. For example, in the case of bakery products, Bacenetti et al. (2018) showed, through an LCA study, that shelf-life extension can reduce food losses and food environmental impacts, which can be applied to other food industries. Yadav and Garg (2019) studied the biotransformation of treated bakery effluents (bakery sludge) into a valuable raw material using vermicompost. Cappelli and Cini (2021) proved that there are several innovations and improvement strategies, using a "cradle to grave" LCA approach, capable of increasing the sustainability, productivity, and final quality of bakery products.

LCM specialists have envisioned a window of opportunity as technological progress and economic development lead to a greater interest in integrating the sustainability agenda into business decision-making. This includes new approaches for assessing impacts on natural capital, environmental management, and corporate reporting. Amid a greater interest in how companies use different types of capital and generate sustainable value, LCM has the potential to illustrate the links between corporate finance and strategic performance (Lugt 2015). Thus, initiatives in LCM can contribute to a more sustainable production model in the bakery sector.

The main motivation of this study was to bring insights in a complete and concise way about improving the management of production processes in bakeries, based on the life cycle thinking. The findings shown in this research can help the implementation of LCM, through investments in marketing, improving waste management, product labeling, hotspots analysis in the sector, sustainable consumption and production, the relationship between stakeholders, and through tools that can help promote sustainability in the bakery sector and other sectors that offer similar products such as restaurants and snack bars.

\section{Methodology}

The study was developed in Teresina, Piauí, Brazil, in a modern chain of bakeries (eight establishments) and a traditional bakery (one establishment). It is known that an analysis based on only nine companies might appear to be limited when aiming to describe one entire sector. However, we found that the establishments were very similar even with variations in size, the number of employees, and equipment. In addition, they represent the reality of most Brazilian bakeries in different regions. Thus, we did not see the need to visit other companies to achieve the research objective once the visits became repetitive and the responses were very similar.

The visits aimed at getting to know the sector and verifying the environmental/social management practices, through questionnaires applied to managers (Appendix A). In the first moment, it was known the offered products, the machines, and equipment used in the production process, the management of the waste, and the practices of environmental, social, and economic sustainability. Also, issues such as product labeling, strategies for choosing suppliers, the socioenvironmental actions developed (if any), the destination of excess production, and the reuse of products were addressed.

Besides the field approach, the study was structured based on the book Life Cycle Management. LCA CompendiumThe Complete World of Life Cycle Assessment (Sonnemann and Margini 2015), which brings the concepts and potentialities of applying LCM in various economic/industrial sectors. The topics covered in the book were discussed aiming at the application of LCM in the bakeries: (1) implementation of sustainability in bakeries; (2) management tools to assist the implementation of life cycle management in bakeries; (3) life cycle sustainability assessment and social responsibility applied to bakeries: product labeling, product declarations, and product certifications; (4) integration of life cycle management in small and medium-sized companies such as bakeries; (5) creating sustainable value with life cycle management through hotspot analysis; and (6) from sustainable production to sustainable consumption.

The Plan, Do, Check, and Act (PDCA) Cycle and the SWOT Matrix, whose acronym comes from the English terms Strengths, Weaknesses, Opportunities, and Threats, were also used as tools to assist the implantation of LCM. Finally, a roadmap for implementing LCM in bakeries was proposed, based on a re-reading of Sonnemann and Margini (2015), with direct and practical contributions to the LCM application in bakeries and other commercial/industrial sectors. Figure 1 shows the research design with all the methodological procedures adopted in this study.

\subsection{Characterization of the bakery sector}

Brazilian bakeries have increasingly diversified to adapt to the demands of the modern market. These establishments, which previously offered only bread and its derivatives, today have become companies with a wide variety of products and services. According to the Brazilian Micro and Small Business Support Service (SEBRAE 2016), there are four main categories of bakeries: (1) traditional - traditional bread and sweets, snacks, and ready-to-eat foods; (2) 
Fig. 1 Methodological procedures adopted in this research. Source: Authors

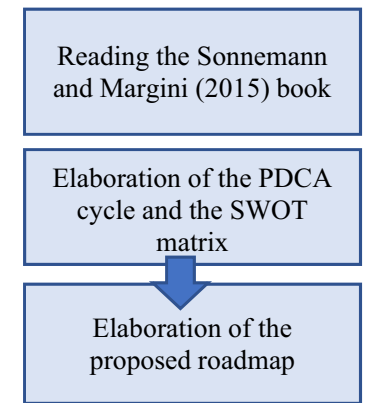

Source: Authors
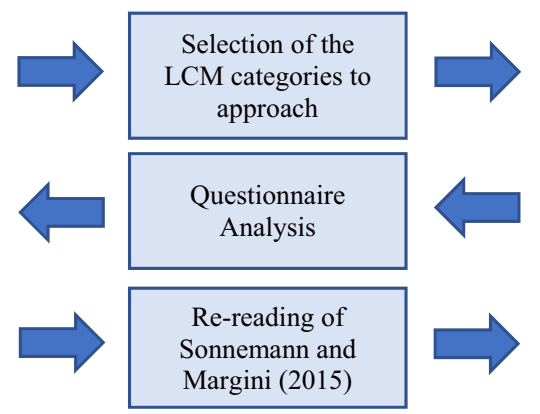

Definition of the sector and construction of the questionnaire

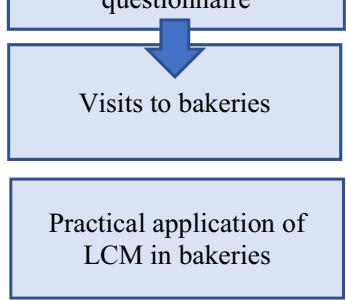

convenience - a wide range of products, offering all the convenience to the consumer so that he does not need to go to another location; (3) express - agile service with a service focused on snacks and meals; and (4) boutique/ boulangerie - a bakery with premium quality products and/or brand recognition in the market.

In Brazil, there are around 64 thousand establishments in the bakery sector, generating 850 thousand direct jobs and more than 1.85 million indirect jobs throughout the country. Small and micro-enterprises account for $96.3 \%$ of the market (SEBRAE 2016). In 2020, the sector had a turnover of $\mathrm{R} \$ 91.94$ billion (around 17.73 billion American dollars). Despite the significant amount, the value represents a drop of $-3.3 \%$ compared to the year 2019. This drop-in gross sales after 13 consecutive years of growth can be attributed to the global economic crisis generated by the new Coronavirus pandemic (COVID- 19) (Associação Brasileira da Indústria de Panificação e Confeitaria - ABIP 2020).

The Brazilian bakeries are similar to others around the world. However, some particularities may be different. According to Galli et al. (2020), Brazilian consumers consider the recommendation of friends, tradition, and the desire for a new consumption experiences important factors when choosing a bakery. Passini et al. (2020) affirm that most waste generated in Brazilian bakeries is organic

(about 58\%). To understand the segment and identify how the sector has evolved, establishments (modern bakeries) were visited where supermarket items are sold, such as cleaning supplies, hygiene products, fruits, and vegetables, in addition to bread and their derivatives. Furthermore, these bakeries have a dining space and make snacks and cakes to order. To compare establishments within the sector, a traditional bakery was visited, where only products such as bread, cakes (savory and sweet), cookies, and biscuits are sold. In the traditional bakery, there is no marketing of supermarket items, as well as no dining space. The description of the visited bakeries is in the topics discussed in Sects. 2.1.1, 2.1.2, and 2.1.3.

\subsubsection{Modern bakeries}

Bakeries from a bakery chain that have a modern format (convenience/express) were visited, which includes the sale of supermarket items and have space for meals. To establish the differentiation, a bakery that maintains the traditional format was also visited; that is, it only sells bread and its derivatives (snacks, sweet and savory cakes, cookies, crackers, and toast). The main differences between these two types of establishments are described in Table 1.

Table 1 Main differences between the modern bakery and the traditional bakery

\begin{tabular}{lll}
\hline & Modern bakery & Traditional bakery \\
\hline Number of companies visited & 8 & 1 \\
Number of employees & 10 to 15 (each establishment) & 17 \\
Number of equipment & 12 to 15 (each establishment) & 14 \\
Business hour & $06: 00$ am to 10:00 pm (every day) & $10: 00$ a.m. to 8:30 p.m. \\
& & (Monday to Saturday) \\
Donations & Specific production & Specific production \\
Waste management & Selective collection, composting & Partially selective collection \\
Marketing actions & TV and radio & None \\
Choice of suppliers & Price and quality & Tradition \\
Type of administration & Contracted managers & Family administration \\
Engagement on environmental issues & None & None \\
Knowledge in LCM & None & None \\
\hline
\end{tabular}


The opening hours are from 06:00 a.m. to 10:00 p.m., throughout the week. French bread is prepared at night and goes through the fermentation process during the night, to be baked in the morning. The quantity of bread and other products produced is calculated to avoid waste. The overproduction of French bread is used to make breadcrumbs, and the leftovers of other types of bread and sweet cakes are used to make toast. These bakeries make snacks and cakes to order, and some establishments serve meals at lunchtime. All serve breakfast from 06:00 a.m.

There is a defined quantity of bread for donation, destined to different institutions; therefore, the production surplus is not donated, but reused in the stores themselves. There are, on average, 15 to 20 employees per store, who are divided into different work shifts. The equipment used in production is electric ovens, slicing machines, mixers, and industrial blenders, freezers, and refrigerators.

Suppliers are chosen considering both the lowest price and the quality of the raw material. All suppliers are in Teresina, from packaging to items used in food manufacturing. Among the most consumed inputs are wheat flour (approximately 10 bags of $50 \mathrm{~kg}$ per week, on average), and eggs; however, the consumption of electricity represents one of the highest costs for establishments, according to the managers.

The modern bakeries do the selective collection of waste and have separate bins inside the stores. The waste (glasses, papers, cans, plastics, polystyrene, etc.) is stored separately and collected by the city hall or the Emaus ${ }^{4}$ community. Organic waste is collected by a private collection company for composting. The bakeries have marketing strategies with advertisements on TV and radio.

\subsubsection{Traditional bakery}

The traditional bakery has different opening hours (10:00 a.m. to 8:30 p.m., Monday to Saturday) and does not open on holidays and Sundays. French bread is only made in the afternoon. The manager says that no chemical additives are used in the bread dough, which is baked immediately after mixing the ingredients. The quantity produced is calculated so that there are no leftovers; usually, the bread runs out before the bakery closes. When there is a small production surplus, the items are divided between employees, or they make toast for sale the next day. The staff consists of confectioners, bakers, cashier operators, attendants, and a manager. The machines and equipment are ovens (three electric and one gas), refrigerators, freezers, slicing machines, and scale.

According to the manager, the suppliers have been the same for approximately 17 years. What determines the

\footnotetext{
${ }^{4}$ Community formed by collectors who use waste for recycling. Available in http://www.emausdeteresina.xpg.com.br/histo.html
}

choice of suppliers is their loyalty to them (tradition). Factors such as lower prices are not considered, as the company trusts in the quality of the raw material acquired long ago. The bakery produces a set amount for donation. Among the establishments served there are the Association of the Carmelite Sisters, the Association of the Blind, two Spiritism Centers, and the "Pode Ajudar" project.

Therefore, donations are not made with excess production, but with a part of products that are specifically intended for this purpose. Regarding waste, cans, bottles, and oil used in frying are collected for recycling, and the oil is used for manufacturing soap. The other residues, such as food scraps, raw materials, and various packages, are not separated but are collected together by the city hall.

\subsubsection{Comparison between modern and traditional bakeries}

In both modern and traditional bakeries, managers do not know the meaning of "life cycle," "life cycle management," or "life cycle assessment." They never had access to informative material on subjects related to these themes and, for this reason, they did not show, until now, interest in applying tools that could improve the production processes from the environmental point of view together with the economic and social objectives of the enterprises.

Concerning management, it is noted that the administration of the traditional bakery is carried out by the family, while in the modern bakeries, the managers/administrators are selected to manage the enterprise. These managers usually have a degree in administration, which raises the quality of management, given the knowledge and specialization that training in higher education provides. This is important because the greater the knowledge, the greater the tendency to improve production processes, seeking better efficiency and effectiveness, which includes environmental issues.

Source: Authors.

\section{Results and discussion}

\subsection{Implementation of sustainability in bakeries}

In the visited bakeries, it was possible to realize that thinking about the life cycle is still far from reality. The managers interviewed do not have any knowledge about LCA or LCM, although they develop some practices, such as the separation of waste and reuse of products that contribute, in some way, to sustainability in the routine of these companies.

The results showed that the choice of suppliers does not consider environmental issues and communication with customers does not evoke these factors. There is no concern with the value chain, since the origin of the raw material, 


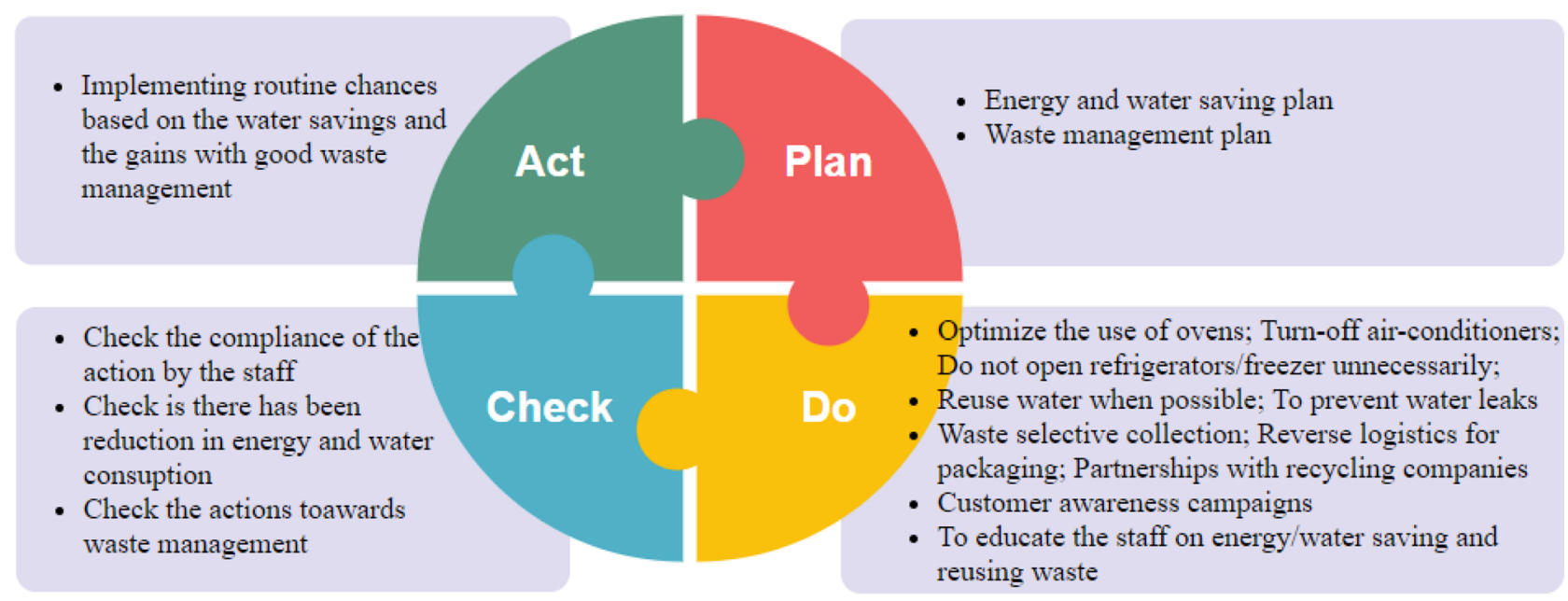

Source: Authors

Fig. 2 Simplified example of using the PDCA cycle tool in bakeries for energy/water saving and waste management plan. Source: Authors

the destination of the products, and communication with customers do not bring relevant issues from the environmental point of view. An example of this is that the materials are purchased considering the price, quality, and tradition. There is no concern in purchasing products from companies with environmental certification, which means that the fact of having a certification is not a differential in the option for suppliers.

Thus, to achieve this objective, it is necessary to disclose LCM among managers of smaller companies, such as the bakeries, to teach about the importance of knowing the entire life cycle of products, processes, and services, to adapt the practices and adopt other actions that may contribute to a more sustainable production from an economic, social, and environmental point of view. Once managers have taken possession of this knowledge, interest in applying it to their business routines may grow. Thus, the engagement of LCA and LCM professionals in the dissemination of knowledge about the tools can sensitize managers to visualize the benefits for the company, as a whole, and for society.

\subsection{Management tools to assist the implementation of Life Cycle Management in bakeries}

LCM has an integrated management structure of techniques and procedures, connecting different operational concepts, policies, systems, methods, tools, and data that incorporate environmental, economic, and social aspects throughout the life cycle of the process/product/service, bringing the life cycle thinking to business practice (Gmelin and Seuring 2014). The choice of the best application tools for LCM depends on the main objective of the company, and it is important to pay attention to communication with shareholders and interested parties, customers, public authorities, consumers, and suppliers. Medeiros et al. (2018) demonstrated, in a study on the Life Cycle Canvas tool, the feasibility of using support tools, which can promote complete management of a project at all stages of its life cycle, confirming the importance of choosing the right tools according to the company's goals.

The PDCA cycle (Fig. 2) and the SWOT Matrix (Fig. 3) are useful for organizations, such as bakeries, as they help in the establishment of attainable goals and the monitoring of their reach, within the context of the LCM. It is important that companies establish plans, in both the short and long terms, but that they are achievable targets. Failure to meet the targets, in addition to leading the organization to discouragement regarding its actions, can cause losses with environmental and social sustainability and have negative economic effects that can compromise the organization.

The PDCA cycle is performed through the definition and implementation of an action plan, checking the objective's achievement, or adjusting the necessary actions to continue the process towards the reaching of the goals (Gemechu et al. 2015). The PDCA Cycle is regulated by the ISO 9001 Standard (International Standard 2015), which contains the requirements for the implementation of quality management systems in organizations. Although it is not a specific tool for environmental issues, it can be used with this focus, for example, to assist in the management of renewable energy (Liu and Li 2019) and implementation of Cleaner Production programs in beverage industries (Silva et al. 2017).

From results obtained in the visited bakeries, it was possible to see that there are actions, for example, to save energy, such as optimizing the use of ovens, turning off air conditioners from time to time, not opening refrigerators and freezers unnecessarily, and optimizing the use of other equipment 


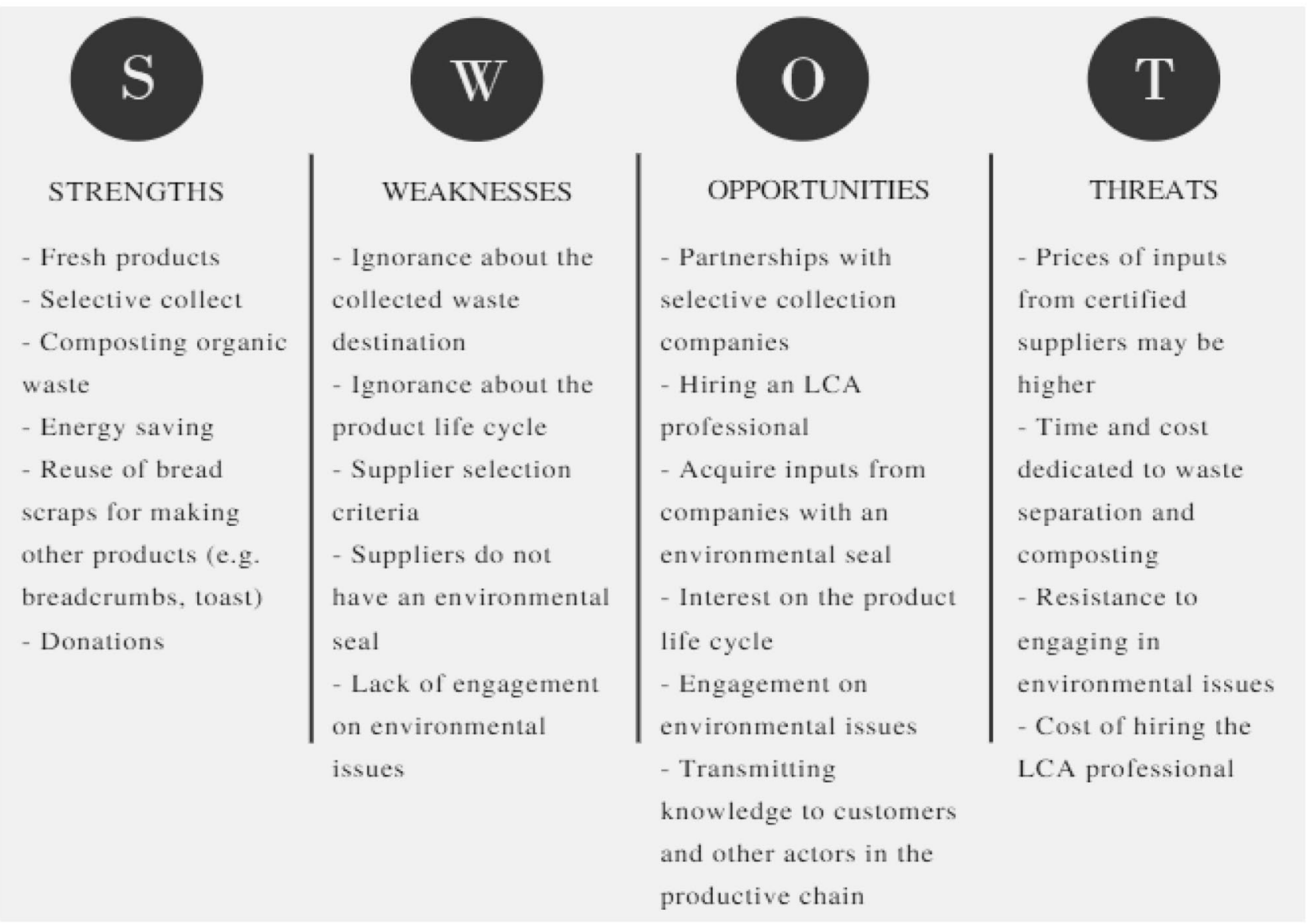

Fig. 3 Example of the SWOT analysis application regarding environmental sustainability issues in bakeries. Source: Authors

(such as mixers, slicing machines) that target the economy in monetary terms. None of the managers reported thinking about environmental problems when adopting these attitudes.

Planning aimed at saving energy/water, raw materials, and optimizing processes, for example, can trigger practical (and sometimes simple) actions compatible with the ambitions of LCM, such as those applied in the visited bakeries resulting in environmental benefits and favoring the best economic performance. Thus, the application of the PDCA cycle in bakeries can help, in both sales and profit goals, as well as in environmental and social issues. Another result found from the research is the example of the application of the SWOT Matrix for environmental issues is in Fig. 3.

The Swot Matrix is a tool used to compare the resources, or the lack of them, with what happens in the world outside the company. In addition, it assists in transforming threats into opportunities, overcoming weaknesses, and elevating internal or external strengths in the organizational environment. This management tool can identify the areas in which the company needs to change and improve (Albuquerque et al. 2017). Bakeries have as a strength some positive attitudes, such as the reuse of bread for making other products (for example breadcrumbs and toast), contributing to the reduction of waste, and generating gains in terms of the sale of a product that would be lost. However, one of its biggest weaknesses is the fact that there is no knowledge about the life cycle due to the lack of interest in engaging in environmental issues.

In this case, an opportunity to improve the LCM in these companies would be to hire an LCA professional to guide, using the tool, on the environmental impacts throughout the life cycle of the products, processes, and services involved in the bakery business. It was possible to perceive from the results of the research that the threat that could prevent the hiring of this professional could be related to the cost. However, it is important to make it clear that this type of investment can result in a financial return in the medium and long terms since economic issues are also covered by the LCA.

In bakeries, LCM can provide an improvement in the performance of production processes, from the selection of suppliers and communication with customers to the final disposal of waste. Life cycle thinking drives decision-making so that impacts can be mitigated across the value chain. Svanes et al. (2018) showed, in their study, that the highest 
potential for the reduction of environmental impact, in bakeries, lies in reducing product wastage at the retail and consumer stages. The use of LCA to assess the environmental impacts of bakery production processes can indicate at what stage are the greatest impacts, and what are they, aiming at the search for solutions to mitigate aggressions to the environment, linked to economic and social benefits.

Another tool that can assist in the implementation of the LCM is Environmental, Social, and Governance (ESG). In the corporate world, ESG means the incorporation of environmental, social, and governance issues as criteria in the analysis, going beyond the traditional economic and financial metrics and, thus, allowing companies to be assessed holistically. ESG is a management tool that can maintain and improve corporate reputation (XIE et al. 2019).

Kocmanová and Simberová (2014) state that the factors for ESG fall into three measurement categories: environmental (investments, emissions, source of consumption, waste), social (society, human rights, labor practices and decent work, responsibility for the product), and corporate governance (monitoring and reporting, corporate governance effectiveness, corporate governance structure, compliance). These factors contribute to the measurement of corporate sustainability performance for the development of sustainability reports and can assist LCM initiatives in large, medium, and small companies, such as bakeries.

The results pointed out that stakeholder engagement is the key to improving corporate environmental policy and sustainable development. Given the diversity in ESG reporting, comparability of ESG strategic performance is difficult. It is important to develop an ESG disclosure index, which companies can use as a legitimacy tool so that external stakeholders can reliably measure and compare companies' ESG performance and the integration of sustainability into the strategic planning process (Lokuwaduge and Heenetigala 2017). Thus, the use of ESG reports can assist stakeholders in implementing LCM strategies in bakeries.

\subsection{Life cycle sustainability assessment and social responsibility applied to bakeries: product labeling, product declarations, and product certifications}

The importance of social responsibility (SR) in the value chain is related to the life cycle sustainability assessment (LCSA), in the context of sustainable development. LCSA is a combination of three different LCA techniques: environmental LCA, social LCA, and cost LCA, while SR refers to the entrepreneur's obligations to follow policies for decision making in terms of society's goals and values, identifying the negative social, environmental, and economic impacts, real and potential, during the entire life cycle of an organizational project or activity (Mazijn and Revéret 2015).
Several documents cover the meaning of SR, among them the ISO 26000 Standard (International Standard 2010); the United Nations Global Compact, regarding the implementation of the Sustainable Development Goals (SDG) and the 2030 Agenda (Platforma Agenda 2030 2019); the Global Reporting Initiative (GRI 2017); and The Organization's Guidelines for Economic Cooperation and Development (OECD) for Multinational Enterprises (Brasil 2018). According to Mazijn and Revéret (2015), SR leads to an obligation of transparency that guides companies to develop measuring instruments for the social and environmental impacts of their activities.

In the visited bakeries, SR is more associated with the donation of bread and other items to entities and associations. The results found showed that managers do not have a vision of the complete value chain and do not think of environmental/social impacts as part of the company's responsibility to society. SR is often confused with the practice of good deeds. It is certain that they are not exclusionary situations and must go together (good actions and reduction of negative impacts).

A starting point is to inform managers, through training courses, lectures, and workshops, about the range of impacts that bakeries can cause. LCA is a tool for the dissemination of this knowledge, since it demonstrates, through analysis, the environmental, social, and cost impacts of products, processes, and services, providing the search for alternative production models more aligned to the SR of these companies.

The proliferation of information such as the external communication of product resources is part of LCM, and it is necessary to provide consumers with information about the characteristics of products and services. The communication of data about the product, by the manufacturer, can be from different forms: oral, written, formalized, informal, standardized, in tags, labels, etc. Some are mandatory, prescribed by national or international regulations/standards, and some are voluntary (Rubik 2015).

Among the mandatory items that must appear on the labels of food products, determined by the Brazilian National Health Surveillance Agency (ANVISA), are those contained in the Collegiate Board Resolutions: RDC 259 (Brasil 2002), RDC 359 (Brasil 2003), and RDC 360 (Brasil 2003a) about the expiration date, data on the establishment, list of ingredients, product origin, manufacturing batch, nutritional information, allergens, lactose, and liquid content.

The information needs of customers and suppliers are different, which requires an appropriate strategy for their transmission. For some, it needs to be condensed as provided by the labels; others need more detailed data. Resellers need the information to respond to business requests in the supply chain or to compete in the market, while consumers demand information that is easy to understand, with approaches that differentiate products within the same group. Successful 
Fig. 4 Example of a label showing environmental sustainability information. Source: Adapted from KAREIVA et al. (2015)

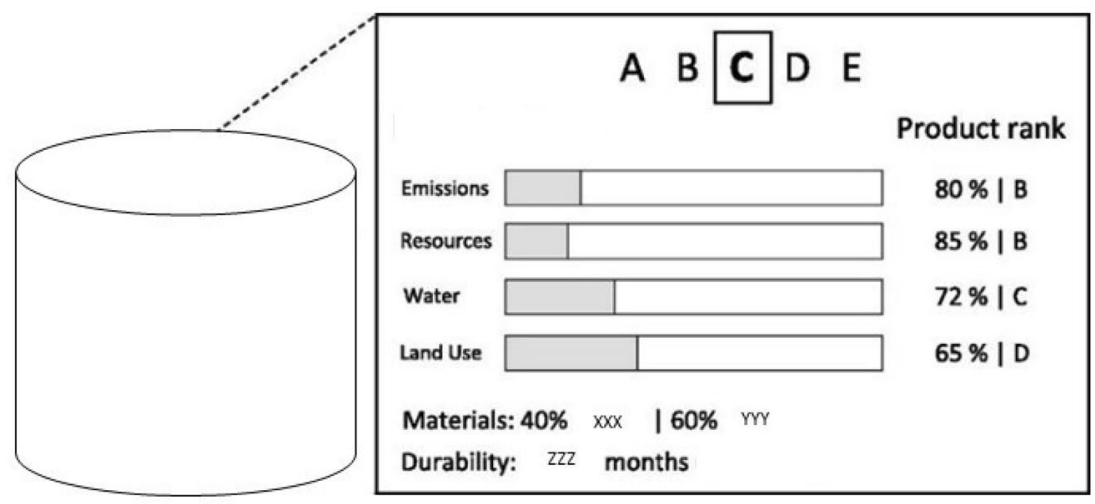

Source: Adapted from KAREIVA et al. (2015). reception by consumers can increase the sales of labeled products and result in reductions of environmental loads (Rubik 2015; Castka and Corbett 2016).

Labeling is a step towards integrating and adjusting the relationship between the buyer and the manufacturer. It can even contribute to the implementation of technologies for cleaner production, rational use of material and energy resources, manufacturing products that are safe for human health and the environment, improving competitiveness in the international market, increasing export potential, and reducing investment risks (Tsaruk and Shpileva 2016).

The information contained in the labels and tags can help customers to compare products and prioritize them according to different criteria, including environmental ones. The labels have the advantage of being the channel for disseminating additional information that is quick to understand and easy to recognize, helping the customer in his choices (Ramírez et al. 2015). Therefore, it is up to the life cycle management to provide information that can influence the increase in sales since this type of data indicates the concern with environmental issues and, more than that, compliance with them (Rubik 2015). Companies that are operating following environmental policies must transmit this information along the chain both to the intermediate consumer (reseller) and to the final consumer. Only with this information, the consumer will be able to choose those companies that follow environmental legislation.

The results showed that bakeries have a quite simple product labeling system. The labels of the items produced in the establishment bring data such as weight, price, date of manufacture/validity, and bar code, which are mandatory, according to ANVISA: RDC 259 (BRASIL 2002), RDC 359 (BRASIL 2003), and RDC 360 (BRASIL 2003a). Some items, purchased from third-party resellers, such as canned products, soft drinks, and yogurts, have more elaborate labels with nutritional information, for example.

Environmental issues such as indications about low environmental impact production standards are not communicated on the labels of products manufactured in these establishments. One reason is that environmental concern does not permeate the business decisions of these companies; consequently, there are no results to be communicated to customers. Figure 4 is an example of what it could contain as environmental information on a label of food products, and Fig. 5 contains the application to bread.

The environmental labeling can contain data on the different stages of the production process simultaneously (LCA of the product), use of clean technologies, and waste management (final disposal). Other environmental information refers to the content limits of a substance considered harmful to human consumption, indicating the tolerable limits of certain pollutants and, also, referring to the energy consumption performance of certain equipment (Moura 2013). Thus, the research proved that, as important as developing environmentally sustainable actions in production processes and communicating them properly, it is necessary to educate the consumer to understand the meaning of these actions and to incorporate this knowledge in their purchasing decisions.

\subsection{Integration of Life Cycle Management in small and medium-sized companies such as bakeries}

Bakeries can apply LCM tools to the organization's processes as a whole. The evaluation of opportunities, risks, costs, sales, and the maturity of the business are decisive in the search for more sustainable processes, from the socioenvironmental point of view, that result in economic advantages. In this context, even in small companies such as bakeries, information technology (IT) solutions are useful to boost the value of sustainability approaches.

IT, with the corresponding databases, maintains the possibility of internal management transparency, as well as control over production processes. Collaboration is important, not only internally, but also between stakeholders, the supply chain, and customers. It was possible to notice that bakeries use IT systems to control sales, stocks, payments, 


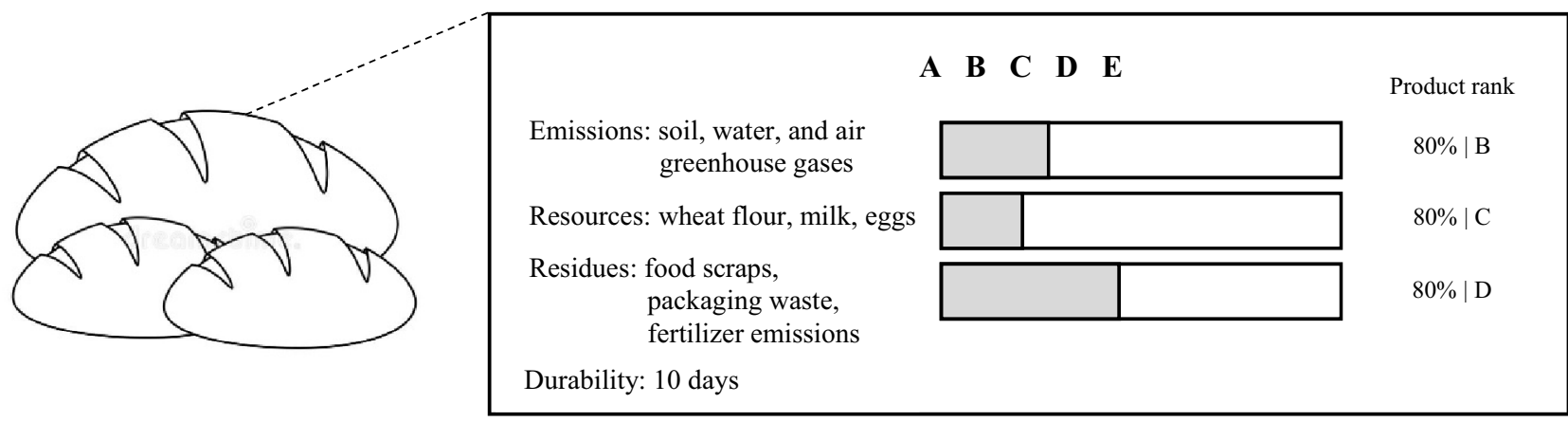

Source: Authors. Source of figure: https://pt.dreamstime.com/alimento-do-trigo-de-p\%C3\%A3es-empreto-e-branco-image 137605155

Fig. 5 Example of a label for bread showing environmental sustainability information. Source: Authors. Source of figure: https://pt.dreamstime. com/alimento-do-trigo-de-p\%C3\%A3es-em-preto-e-branco-image137605155

and receipts, but without envisioning the possibility of using these tools with an environmental focus. LCM applied in collaboration and partnerships with companies also depends on effective communication strategies. IT tools allow the creation of optimization services, capable of providing information to improve the system operation regarding clients (Lee et al. 2017), which can also be applied in terms of cost or environmental efficiency.

In this sense, the results pointed out that bakeries can optimize their processes using resources such as the alignment of input orders, with periodic deliveries, avoiding impacts with transport. As noted, orders are placed by each establishment, according to their needs. The integration between bakeries would make it possible to optimize the inputs delivery, contributing to the reduction of dislocations (reducing emissions), in addition to providing gains in terms of routine organization. With prior and coordinated programming amongst different establishments, it is even possible to obtain financial gains through economy of scale. ${ }^{5}$

The possibility of exchange between bakeries and other companies of the food sector, as associations, nongovernmental organizations (NGO), and schools, can contribute to several aspects, among them, reduction of reusable/recyclable residues, as long as there is logistics for this, generating economic and environmental gains, in addition to fulfilling the social role of the enterprise. In the visited bakeries, overproduction is used to manufacture new items, such as breadcrumbs and toast. The donated items do not come from leftovers, but there is a specific production destined for this purpose.

\footnotetext{
${ }^{5}$ Economy of scale happens when the increase in production results in decrease in the average cost of the product (Dicionário Financeiro 2021). The concept applies to purchases. The greater the volume of purchases, the lower the cost per unit of product.
}

Regarding waste, the management is different in the modern bakeries, which have a selective collection, while the traditional bakery does not adopt this practice. However, separating the residues does not guarantee the proper destination. From the results of the visits, it was possible to perceive that managers do not know if the items are recycled or reused, which indicates disinterest in the entire chain. LCM considers the entire value chain, including final disposal. Styles et al. (2016) affirm that the use of the composting technique for food waste contributes to the reduction of greenhouse gas emissions. This initiative can be applied in the bakery sector due to the volume of food waste generated in the production process.

\subsection{Creating sustainable value with Life Cycle Management through hotspot analysis}

LCA is an instrument to identify resource use hotspots and associated environmental charges, while material flow cost accounting is a financial instrument used to monetize (in) efficiency and demonstrate resources linked to products. Both are valuable LCM instruments to enable improvement in investment decision-making and support communication between the different actors (Rieckhof and Guenther 2018). The accounting of a company must be at the service of LCM, in an integrated manner. Both the estimation of environmental costs, as well as the costs related to the enterprise, should help the establishment of scenarios that bring innovation and operational efficiency.

The hotspot analysis technique is one of the LCM tools that has been used in different analytical disciplines within organizations (for example, new product development, purchasing) and in support of the green economy and the SDG. It can be used to inform government policy priorities, drive growth and innovation in business, and empower citizens (Barthel et al. 2015) and in small businesses like bakeries. 
This type of analysis involves simplified methodologies, to identify the "hot" or problematic points, aiming at an immediate action in those points.

Chiriaco et al. (2017) showed that wheat cultivation is the hotspot in the life cycle of wholemeal bread production. On the other hand, the results found in the visited bakeries showed that one of the important points is related to energy consumption, the highest production costs, as informed by the managers. The amount of energy consumed, in general, is high in most production processes. Thus, the LCA can indicate at which stage of the production process there is a greater consumption of energy, for example, to enable the search for suitable solutions from the energy point of view.

The identification of environmental hotspots supports the design of solutions that will have fewer impacts throughout each phase of the product or service life cycle (Zomer and Miguel 2016). However, the lack of a common global approach to the hotspots analysis can result in inconsistency in the methodological approach, causing difficulties in comparing conflicting studies results and sustainability information in the market (Barthel et al. 2015). Therefore, due to its simplicity, it is necessary to standardize communication when using such methodologies so that the appropriate use and communication of sustainability information derived from the hotspot analysis and other life cycle approaches can guide on the best management practices in the production processes.

\subsection{From sustainable production to sustainable consumption}

To achieve sustainable production and consumption patterns, LCM needs to be absorbed by complete production chains, which include small and medium-sized enterprises. From a commercial point of view, this represents a question of competitiveness, as these companies have been pressured by customers and legislators to supply more information about the impacts of their products and take responsibility for them. Therefore, a sectoral and regional approach is necessary to promote the implementation of LCM in small and mediumsized enterprises (Adibi et al. 2015) such as bakeries.

One of the main consumer's roles, within the value chain, is to dictate their needs so that the market meets them, including pressing on environmental issues (Boström et al. 2015). In the case of bakeries, the results showed that once consumers have changed their interests over time, the offer of products has also changed to adapt to the new reality. Bakeries that only provided bread now supply a range of products from meals to supermarket items. According to the manager of one of the visited bakeries, there has been an increasing search for organic products, which demonstrates the change in consumer behavior.

For the consumer to be able to indicate his choices and dictate the rules of the market, towards environmental issues, he/she must know the subject, especially on the life cycle

Table 2 Mapping of processes related to the environmental impacts involved in the bread's life cycle

\begin{tabular}{|c|c|c|c|c|c|}
\hline \multicolumn{3}{|c|}{ Bread production } & \multicolumn{3}{|l|}{ Environmental impacts } \\
\hline Stage & Activity & Inputs & Emissions & Residues & Use of resources \\
\hline Raw material & Wheat cultivation & $\begin{array}{l}\text { Seed, soil, compost, } \\
\text { water, and fertilizers }\end{array}$ & $\begin{array}{l}\text { Emissions to the soil, } \\
\text { water, and air }\end{array}$ & $\begin{array}{l}\text { Foliage, roots, ferti- } \\
\text { lizer, and/or pesticide } \\
\text { packaging }\end{array}$ & Water, soil \\
\hline Production & Bread making & Wheat flour, milk, eggs & Greenhouse gases & $\begin{array}{l}\text { Mass scraps, raw mate- } \\
\text { rial packaging }\end{array}$ & $\begin{array}{l}\text { Oven energy, water for } \\
\text { cleaning }\end{array}$ \\
\hline Transport & Transport to retail & - & Greenhouse gases & - & Fuel \\
\hline Buy/Sell & $\begin{array}{l}\text { Display of products } \\
\text { at the sales } \\
\text { counter }\end{array}$ & - & - & $\begin{array}{l}\text { Food bran, packaging } \\
\text { waste }\end{array}$ & $\begin{array}{l}\text { Energy for lighting and } \\
\text { food cooling }\end{array}$ \\
\hline Use & Ready-to-eat bread & - & $\begin{array}{l}\text { Emissions to the soil, } \\
\text { water, and air }\end{array}$ & $\begin{array}{l}\text { Food scraps, packaging } \\
\text { waste, fertilizer emis- } \\
\text { sions }\end{array}$ & The product itself (bread) \\
\hline \multirow[t]{4}{*}{ Discard } & Reuse & $\begin{array}{l}\text { Leftover bread for sand- } \\
\text { wiches and others }\end{array}$ & Greenhouse gases & - & Bread leftovers \\
\hline & Reutilization & $\begin{array}{l}\text { Leftover bread for toast } \\
\text { or breadcrumbs }\end{array}$ & Greenhouse gases & - & Bread leftovers \\
\hline & Donation & $\begin{array}{l}\text { Leftovers or specific } \\
\text { products for this } \\
\text { purpose }\end{array}$ & Greenhouse gases & - & Bread leftovers \\
\hline & Waste & Bread leftovers & $\begin{array}{l}\text { Greenhouse gases and } \\
\text { nutrient emissions. } \\
\text { For example, landfill } \\
\text { methane }\end{array}$ & Waste & - \\
\hline
\end{tabular}


of products he/she consumes. As an important result from this research, Table 2 contains the mapping of the processes regarding environmental impacts, involved in the bread's life cycle, with essential information for the consumer to know the main activities necessary to produce his "daily bread."

Source: Adapted from SEBRAE (2017).

Economic and social issues are also involved in the life cycle of a product. But, for the consumer to be able to make environmentally conscious choices, he/she must know the impacts involved in the manufacture of a product, under this perspective. Thus, the consumers' behavior, consumption, and lifestyle choices can shape the market. Therefore, it is necessary to create conditions for these choices to be sustainable, firstly educating them to consider environmental issues when choosing certain products. Developing scenarios about lifestyle approaches (for example, "shopping at the local bakery") can support consumers' choice to promote and encourage local commerce, decreasing the impact of dislocation. Noya et al. (2018) proved that increasing the packaging recycling rate and using local ingredients reduce the environmental burden in the bakery sector.

The results found from the visits showed that bakeries can develop and distribute educational/informational materials to the public to increase understanding of what constitutes a "sustainable product" and "sustainable lifestyle." These materials should contain clarifications on the importance of LCA products for reducing environmental impacts, in addition to demonstrating the influence of the entire value chain (e.g., the choice of certified suppliers, who have actions that show concern with environmental issues). TV programs and social media mobilization can be the vehicle to achieve this goal since they can reach a greater number of consumers.

Modern bakeries adopt television marketing actions that aim at increasing sales, fundamentally. Environmental issues are practically not addressed to impact the choice of customers. It is necessary to transform this scenario, including in marketing the environmental approach so that the consumer learns and understands the importance of purchasing products from companies that have sustainable practices. Table 3 shows the analyzed aspects in the bakeries, what was found, and the recommendations for this sector.

Source: Authors.

\subsection{Roadmap for applying Life Cycle Management in bakeries}

Management is performed with knowledge, indicators, and planning. Bakeries can gradually implement LCM, starting with small goals and advancing as knowledge about the ways to apply LCM by the managers of these companies grows. The hiring of a professional specialized in LCA can be the beginning of more sustainable management from an environmental, economic, and social point of view.

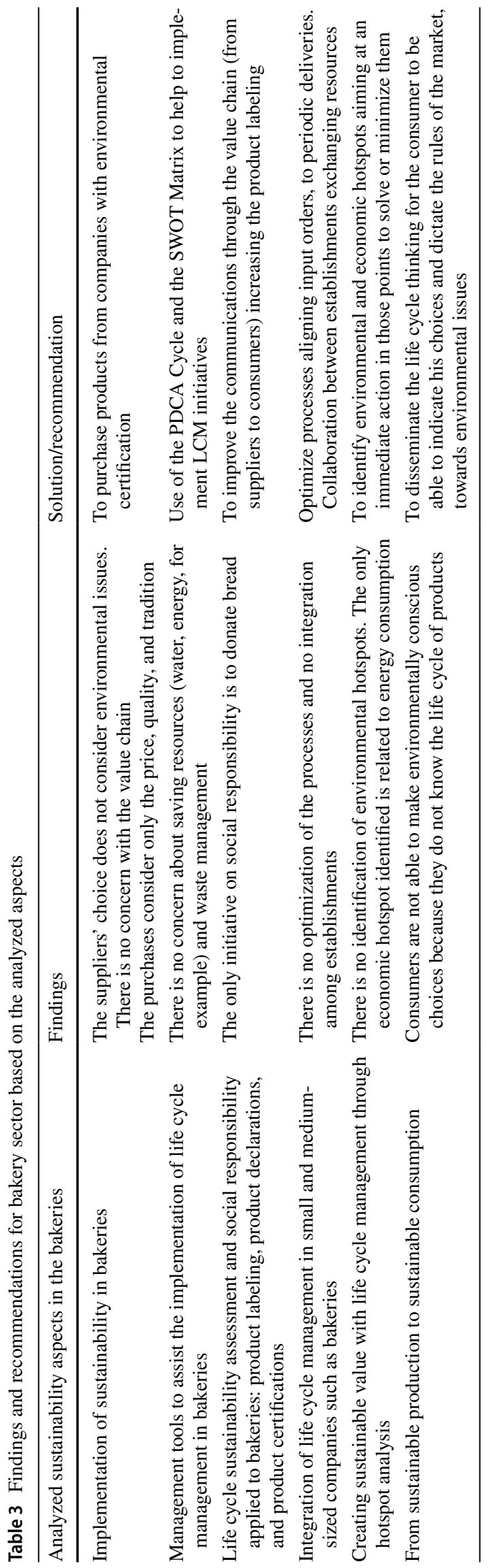




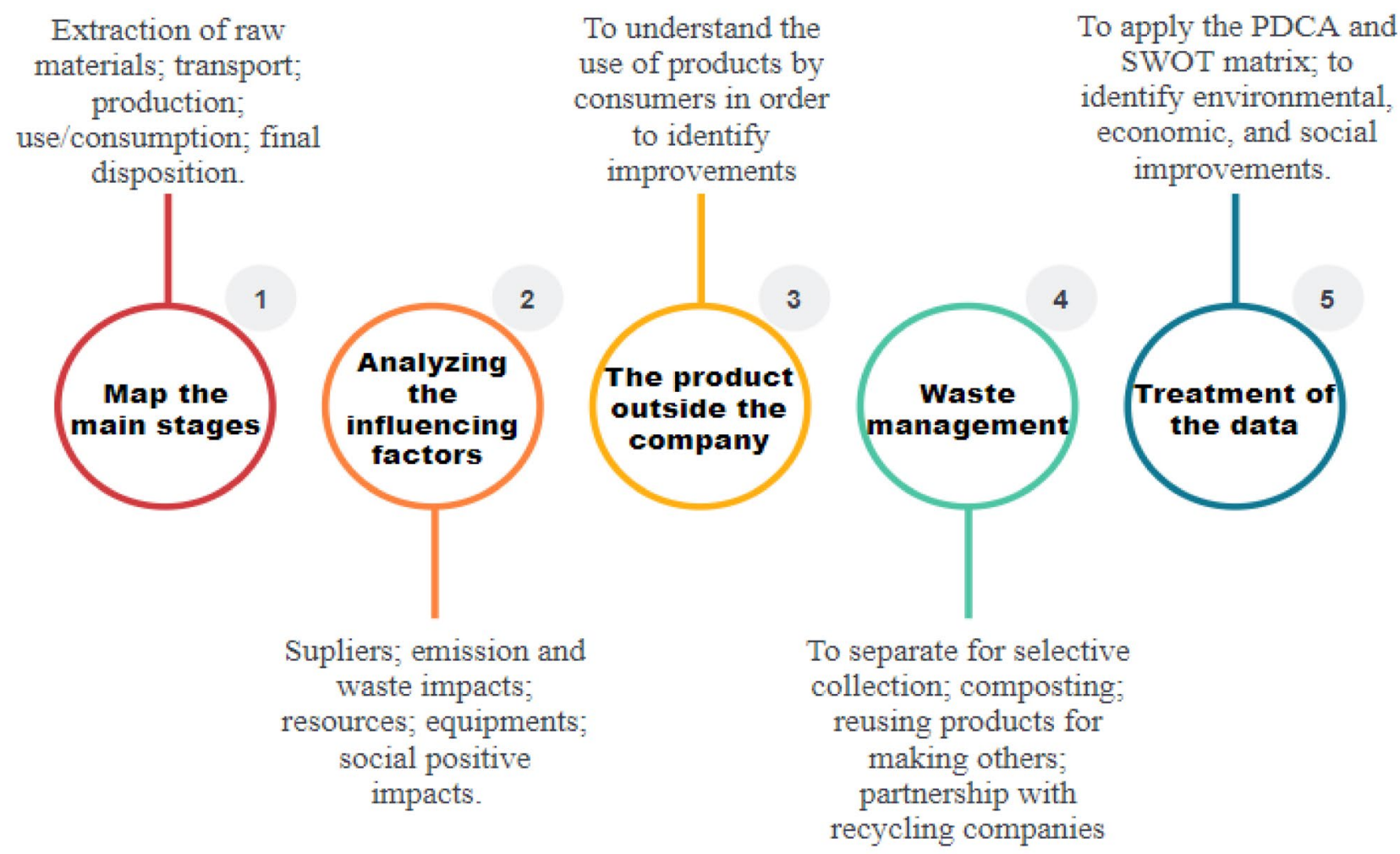

Source: Authors

Fig. 6 Roadmap for implementing life cycle management in bakeries. Source: Authors

Thus, based on the indications of the document developed by SEBRAE (2017) in partnership with the United Nations Environment and the IBICT, and the material about bakeries provided by the SEBRAE Center of Sustainability (SEBRAE 2016), associated with the results found in this research, it is possible to propose a roadmap for implementing LCM in bakeries (Fig. 6).

The first step is to understand and map the main stages that involve the life cycle of products sold in bakeries: extraction of raw materials, transport to production, production, transport for sale, use/consumption, and final disposition. Each stage has different activities and impacts, including the activities of suppliers, customers, and others involved in the sector's production chain.

The second step is to analyze factors that may influence the actions towards more sustainable management, dor example, to know the activities of each stage identified in the first step; know the companies involved, whether suppliers are certified or have environmental seals; purchase of local suppliers, avoiding impacts (for example, emissions) with the displacement of the inputs; identify the resources used (and their quantities) for the operation of the establishment (water, energy, raw materials); acquire equipment (refrigerators, freezers, ovens) that have energy-saving seals (for example Procel ${ }^{6}$ seal); know the types of waste that are generated in the company; and verify the direct and indirect impacts on society (employees, customers, and the community), including positive social impacts (donations).

The third step is regarding the sale and the product outside the company. Standardization is essential to avoid waste, as well as the manufacture of products in minimum quantities for the day's service. It is also necessary to understand the use of products by consumers to identify improvements at the end of their lifespan, for example, to know how people discard the packaging. For this, proper labeling is essential. The information on the labels can indicate the correct destination (e.g., recycling), durability/validity in addition to showing issues such as their impacts (energy consumption in the production phase, quantification of emissions, etc.). Likewise, the communication of these issues through

\footnotetext{
${ }^{6}$ Procel seal is a tool that allows the consumer to know, among the equipment and appliances available on the market, the most efficient and which one consumes the least energy (http://www.procelinfo. com.br/main.asp?TeamID=\% 7B88A19AD9-04C6-43FC-BA2E99B27EF54632\%7D).
} 
the company's marketing is essential, which can be done in several ways (pamphlets, television, social networks, etc.).

The fourth step is related to waste management. Efficient waste management involves simple actions, such as separating for selective collection, composting with organic materials, and reusing products for making others (for example, reusing bread for making breadcrumbs and toast). A major advance in this stage would be the partnership with recycling companies. The bakery can supply waste for recycling companies that return the material for sale or use in the bakery itself (for example, packaging made with recycled plastic, supplied by the bakery). This action can contribute to a circular economy.

The fifth step is the treatment of the data collected in the previous steps for the beginning of the improvement proposal. In this phase, it is possible to apply the PDCA and the SWOT matrix based on the understanding of the impacts (environmental, economic, and social) generated throughout the life cycle of the production and commercialization of bread and other items and, thus, it becomes possible to identify opportunities for investments in improvements that cover environmental issues, together with the improvement of economic and social aspects.

\section{Conclusion}

In the visited bakeries, it was noticed that the challenge for implementing LCM is great, but not impossible. The knowledge of the LCM tools by the managers, so that there is an engagement to prioritize their choices, considering the environmental factors, is something very distant from reality. Although still incredibly challenging, the ideal scenario would be one in which the ideas of life cycle thinking could be spread to society, so that the consumer becomes more demanding.

As seen, the supplier selection criterion, for example, is not done considering environmental aspects and the concern about waste or excessive energy expenditure is only motivated by economic issues. Although in modern bakeries there is a separation of waste, there is no concern about knowing its destination, if it is properly performed or if the reusable materials go to recycling. In the traditional bakery, not all residues are separated, which shows that there is little reuse of them.

These companies have an important social role, as they allocate part of their production to donation to various establishments. However, there is still a long way to go towards sustainable consumption and production. For society to consider environmental issues as a differential for its purchase, it is necessary to communicate it on the labels of the products manufactured by these companies. There is also no approach to environmental issues in the marketing actions of these companies once they have not assumed their socio-environmental responsibility.

Thus, LCM professionals have the opportunity to disseminate this knowledge among bakery managers, to mobilize this sector in the search to improve existing sustainability practices and adopt other actions that may contribute to the environment and society, while promoting economic benefits for the enterprises. The proposed roadmap can be extended to other economic/industrial sectors, in different parts of Brazil and the world. The biggest limitation of the study is in the access to data. Some managers refuse to provide data or provide inaccurate data, which can compromise studies of this nature. Future studies can address precise inventory data for LCA modeling to know the real impacts generated by the bakery sector.

Supplementary information The online version contains supplementary material available at https://doi.org/10.1007/s11367-021-02008-7.

Funding This work was supported by $\mathrm{CNPq}$-- Research grants (Process no. 401320/2016-2 and Process no. 422087/2018-1) and Research Productivity Scholarship (Process no. 304974/2018-8) and FAPEPI (Notice FAPEPI/MCT/CNPq No. 007/2018 — Infrastructure Program for Young Researchers/First Projects Program). Researcher JMMN received funding from $\mathrm{CNPq}$ through the Research Productivity Scholarship (304974/2018-8).

Data availability All data generated or analyzed during this study are included in this published article (and its supplementary information files).

\section{References}

Adibi N, Pasquet V, Roy A, Salamon A, Bricout J, Beutin C, Renault Q, Darul M, Callens FX, Haquette M, Orlans P, Meillier J, Boudehenn J, Reynaud S, Cabaret S, Bogaert C, Demaretz C (2015) Mainstreaming the use of Life Cycle Management in small and medium sized enterprises using a sector based and regional approach. In: Sonnemann, G, Margini M (eds) Life Cycle Management. LCA Compendium - The Complete World of Life Cycle Assessment. Springer, pp 79-90

Albuquerque JV, Brasil BTN, Silva GT, Cruz ACC, Costa MF (2017) Utilização da análise SWOT para a elaboração da estratégia mercadológica. Rev Maiêutica 5:221-234

Associação Brasileira da Indústria de Panificação e Confeitaria ABIP (2020) Com a pandemia, setor de panificação apresenta retração no faturamento de 3,3\%. https://www.abip.org.br/site/ com-a-pandemia-setor-de-panificacao-apresenta-retracao-nofaturamento-de-33/. Accessed 01 July 2021

Bacenetti J, Cavaliere A, Falcone G, Giovenzana V, Banterle A, Guidetti $\mathrm{R}$ (2018) Shelf life extension as solution for environmental impact mitigation: a case study for bakery products. The Sci Total Environ 627:997-1007. https://doi.org/10.1016/j.scitotenv.2018.01.301

Balkau F, Gemechu, ED, Sonnemann G (2015) Life Cycle Management responsibilities and procedures in the value chain. In: Sonnemann G, Margini M (eds) Life Cycle Management. LCA Compendium - The Complete World of Life Cycle Assessment. Springer, pp 195-212 
Barthel M, Fava JA, Harnanan CA, Strothmann P, Khan S, Miller S (2015) Hotspots analysis: providing the focus for action. In: Sonnemann, G.; Margini, M., Ed(s). Life Cycle Management. LCA Compendium - The Complete World of Life Cycle Assessment. Springer 149-167

Boström M, Jönsson AM, Lockie S, Mol APJ, Oosterveer P (2015) Sustainable and responsible supply chain governance: challenges and opportunities. J Clean Prod 107:1-7. https://doi.org/10.1016/j. jclepro.2014.11.050

Brasil. Ministérios da Economia. Diretrizes da OCDE para Empresas Multinacionais (2018) http://www.fazenda.gov.br/assuntos/ atuacao-internacional/ponto-de-contato-nacional/diretrizes-daocdepara-empresas-multinacionais. Accessed 23 May 2021

Brasil. Ministério da Saúde. Agência Nacional de Vigilância Sanitária - ANVISA. Resolução de Diretoria Colegiada - RDC N² 259, de 20 de setembro de (2002) http://www.agricultura.gov.br/assuntos/ inspecao/produtos-vegetal/legislacao-1/biblioteca-de-normasvinhos-e-bebidas/resolucao-rdc-no-259-de-20-de-setembro-de2002.pdf/view. Accessed 24 May 2021

Brasil. Ministério da Saúde. Agência Nacional de Vigilância Sanitária - ANVISA. Resolução de Diretoria Colegiada - RDC No 359, de 23 de dezembro de (2003) http://portal.anvisa.gov.br/documents/ 33880/2568070/res0359_23_12_2003.pdf/76676765-a107-40d9bb34-5f05ae897bf3. Accessed 22 May 2021

Brasil. Ministério da Saúde. Agência Nacional de Vigilância Sanitária - ANVISA. Resolução de Diretoria Colegiada - RDC No 360, de 23 de dezembro de (2003a) http://portal.anvisa.gov.br/documents/ 33880/2568070/res0360_23_12_2003.pdf/5d4fc713-9c66-4512b3c1-afee57e7d9bc. Accessed 24 May 2021

CAPES - Coordenação de Aperfeiçoamento de Pessoal de Nível Superior (2021) https://www-periodicos-capes-gov-br.ezl.periodicos. capes.gov.br/index.php?. Acessed 26 May 2021

Cappelli A, Cini E (2021) Challenges and opportunities in wheat flour, pasta, bread, and bakery product production chains: a systematic review of innovations and improvement strategies to increase sustainability, productivity, and product quality. Sustain 13:1-16. https://doi.org/10.3390/su13052608

Castka P, Corbett C (2016) Adoption and diffusion of environmental and social standards: the effect of stringency, governance, and media coverage. Int J Oper Prod Manag 36:504-1529. https://doi. org/10.1108/IJOPM-01-2015-0037

Chiriacò MV, Grossi G, Castaldi S, Valentini R (2017) The contribution to climate change of the organic versus conventional wheat farming: a case study on the carbon footprint of wholemeal bread production in Italy. J c Prod 153:309-319. https://doi.org/10. 1016/j.jclepro.2017.03.111

Dicionário Financeiro. O que é economia de escala (2021) https://www. dicionariofinanceiro.com/economia-de-escala/. Accessed 13 May 2021

Finance Strategists (2021) Profit Definition. https://learn.financestrategi sts.com/finance-terms/profit/. Accessed 27 Oct 2021

Galli LCLA, Garcia SFA, Marques EF, Lima GB (2020) O comportamento de compra dos consumidores do município de Jaboticabal - SP em relação aos serviços panificação: um estudo exploratório-descritivo. Braz J Bus 2:1548-1560. https://doi. org/10.34140/bjbv2n2-045

Gemechu ED, Sonnemann G, Remmen A, Frydendal J, Jensen AA (2015) How to implement Life Cycle Management in business? In: Sonnemann G, Margini M (eds) Life Cycle Management. LCA Compendium - The Complete World of Life Cycle Assessment. Springer, pp 35-50

Global Reporting Initiative - GRI. AMD's (2017) GRI Index is prepared in accordance with the GRI Standards' Core option. https://www.amd.com/system/files/documents/GRI-Index.pdf. Accessed 12 June 2021
Gmelin H, Seuring S (2014) Achieving sustainable new product development by integrating product life-cycle management capabilities. Int J Prod Econ 154:166-177. https://doi.org/10. 1016/j.ijpe.2014.04.023

International Standard (2010) ISO 26000:2010. Guidance on social responsibility, Geneva

International Standard (2015) ISO 9001: 2015. Quality management systems - requirements. Geneva, 2015

Kareiva PM, Mcnally BW, Mccormick S, Miller T, Ruckelshaus M (2015) Improving global environmental management with standard corporate reporting. Proc Natl Acad Sci 112:7375-7382. https://doi.org/ 10.1073/pnas.1408120111

Kishita Y, Uwasu M, Hara K, Kuroda M, Takeda H, Umeda Y, Shimoda Y (2018) Toward designing sustainability education programs: a survey of master's programs through semistructured interviews. Sustain Sci 13:953-972. https://doi.org/ 10.1007/s11625-018-0546-5

Kocmanová A, Simberová I (2014) Determination of environmental, social and corporate governance indicators: framework in the measurement of sustainable performance. J Business Econ Manag 15:1017-1033. https://doi.org/10.3846/16111699.2013.791637

Lee KW, Lanting MCL, Rojdamrongratana M (2017) Managing customer life cycle through knowledge management capability: a contextual role of information technology. Total Qual Manag Business Excel 28:1559-1583. https://doi.org/10.1080/ 14783363.2016.1150779

Life Cycle Initiative (2021) Life Cycle Management. https://www. lifecycleinitiative.org/starting-life-cycle-thinking/life-cycleapproaches/life-cycle-management/. Accessed 20 June 2021

Liu H, Li B (2019) Design of management system for a variety of marine renewable energy. J Coast Res 83:927-931. https://doi. org/10.2112/SI83-154.1

Lokuwaduge CSDS, Heenetigala K (2017) Integrating environmental, social and governance (ESG) disclosure for a sustainable development: an Australian study. Business Strateg Environ 26:438-450. https://doi.org/10.1002/bse.1927

Lugt CTVD (2015) Taking Life Cycle Management mainstream: integration in corporate finance and accounting. In: Sonnemann G, Margini M (eds) Life Cycle Management. LCA Compendium - The Complete World of Life Cycle Assessment. Springer, pp 227-238

Manda BMK, Bosch H, Worrell E (2015) Sustainable value creation with life cycle management. In: Sonnemann G, Margini M (eds) Life Cycle Management. LCA Compendium - The Complete World of Life Cycle Assessment. Springer, pp129-146

Mazijn B, Revéret JP (2015) Life Cycle Sustainability assessment: a tool for exercising due diligence in Life Cycle Management. In: Sonnemann G, Margini M (eds) Life Cycle Management. LCA Compendium - The Complete World of Life Cycle Assessment. Springer, pp 51-63

Medeiros BC, Araújo VFS, Silva Oliveira MKA (2018) Life Cycle Canvas (LCC): um modelo visual para a gestão do ciclo de vida do projeto. Rev Gest.Proj - GeP 9:87-101. https://doi.org/10.5585/ gep.v9i1.628

Moura AMM (2013) O mecanismo de rotulagem ambiental: perspectivas de aplicação no Brasil. IPEA - Bol. Reg Urban Ambient 7:11-21

Noya LI, Vasilaki V, Stojceska V, González-García S, Kleynhans C, Tassou S, Moreira MT, Katsou E (2018) An environmental evaluation of food supply chain using life cycle assessment: a case study on gluten free biscuit products. J Clean Prod 170:451-461. https://doi.org/10.1016/j.jclepro.2017.08.226

Passini AFC, Chagas P, Rodrigues AC, Costa Junior J, Borba WF (2020) Geração de resíduos sólidos: estudo de caso em padaria de pequeno porte. 3 Congr. Sulam. Resíduos Sólidos e Sustent. Anais Gramado - RS. 1-4 
PLATAFORMA AGENDA 2030 (2019) Acelerando as transformações para a Agenda 2030 no Brasil. http://www.agenda2030.com.br/. Accessed 05 June 2021

Ramírez MP, Hernández MAA, Polanco GA, Morales LFB (2015) Consumer acceptance of Eco-Labeled Fish: a Mexican case study. Sustain 7:4625-4642. https://doi.org/10.3390/su7044625

Rebitzer G (2015) Introduction: Life Cycle Management. In: Sonnemann G, Margini M, (eds) Life Cycle Management. LCA Compendium - The Complete World of Life Cycle Assessment. Springer, pp 3-6

Rieckhof R, Guenther E (2018) Integrating life cycle assessment and material flow cost accounting to account for resource productivity and economic-environmental performance. The Int J Life Cycle Assess 23:1491-1506. https://doi.org/10.1007/ s11367-018-1447-7

Rubik F (2015) Life Cycle Management: labelling, declarations and certifications at the product level - different approaches. In: Sonnemann G, Margini M (eds) Life Cycle Management. LCA Compendium - The Complete World of Life Cycle Assessment. Springer, pp 65-77

SEBRAE - Serviço Brasileiro de Apoio às Micro e Pequenas Empresas (2016) Minha Empresa Sustentável: Padaria. Centro Sebrae de Sustentabilidade - Cuiabá: Sebrae, p 32

SEBRAE - Serviço Brasileiro de Apoio às Micro e Pequenas Empresas (2017) Pensamento do ciclo de vida: negócios conscientes a caminho da sustentabilidade. Cuiabá: Sebrae, p 39

Seidel-Sterzik H, Mclaren S, Garnevska EA (2018) Capability maturity model for life cycle management at the industry sector level. Sustain 10:2496-2515. https://doi.org/10.3390/su10072496

Silva AS, Medeiros CF, Vieira RK (2017) Cleaner production and PDCA cycle: practical application for reducing the Cans Loss Index in a beverage company. J Clean Prod 150:324-338. https:// doi.org/10.1016/j.jclepro.2017.03.033

Simon L (2015) A review of life cycle based ecological marketing strategy for new product development in the organizational environment. J Clean Prod 95:1-15. https://doi.org/10.1016/j.jclepro. 2015.02.022
Sonnemann G, Margini M (2015) Life Cycle Management. LCA Compendium - The Complete World of Life Cycle Assessment. Springer, p 353

Sonnemann G, Gemechu ED, Remmen A, Frydendal J, Jensen AA (2015) Life Cycle Management: implementing sustainability in business practice. In: Sonnemann G, Margini M (eds) Life Cycle Management. LCA Compendium - The Complete World of Life Cycle Assessment. Springer, pp 7-21

Styles D, Dominguez EM, Chadwick D (2016) Environmental balance of the UK biogas sector: an evaluation by consequential life cycle assessment. The Sci Total Environ 560-561:241-253. https://doi. org/10.1016/j.scitotenv.2016.03.236

Svanes E, Oestergaard S, Hanssen O (2018) Effects of packaging and food waste prevention by consumers on the environmental impact of production and consumption of bread in Norway. Sustain 11:120. https://doi.org/10.3390/su11010043

Tsaruk IM, Shpileva YB (2016) Ukrainian realities of labeling of environmentally friendly products. Vìsnik Zitomirs'kogo Derzavnogo Tehnologìcnogo 4:192-201

Xie J, Nozawa W, Yagi M, Fujii H, Managi S (2019) Do environmental, social, and governance activities improve corporate financial performance? Business Strateg. Environ 28:286-300. https://doi. org/10.1002/bse.2224

Yadav A, Garg VK (2019) Biotransformation of bakery industry sludge into valuable product using vermicomposting. Bioresour Tech 274:512-517. https://doi.org/10.1016/j.biortech.2018.12.023

Zomer TTS, Miguel PAC (2016) Proposta para identificação e análise dos hotspots ambientais no ciclo de vida de sistemas produtoserviço. In: XXXVI Encontro Nac. Eng. Prod. - ENEGEP, 2016. João Pessoa. Anais [...]. João Pessoa: ABEPRO 1-14

Publisher's Note Springer Nature remains neutral with regard to jurisdictional claims in published maps and institutional affiliations. 